\title{
硝酸銀を用いた電位滴定法によるシアン化物イオンと ジシアノ銀酸イオンの逐次定量
}

\author{
汀. 藤 元 則* \\ (1985 年 6 月 1 日受理)
}

硝酸銀を用いた電位差滴定法によるシフン化物イオンとジシアノ銀酸イオンの逐次定量法について検 討した．指示電極として金電極を用いることにより，シアン化物イオンとジシアノ銀酸イオンのそれぞ れに対応する変曲点が得られ，逐次定量することができた． 本法により $1 \sim 5 \mathrm{mM}$ のシアン化物イオ ソージシフノ銀酸イオン混合物を $0.3 \%$ 以内の相対標準偏差で精度よく定量できた.

\section{1 緒}

シアン化物イオンとジシアノ銀酸イオンの混合液中の シアン化物イオンの定量には Liebig 法や硝酸銀による 電位差滴定法1)2) 及び電流滴定法3) 8) などが用いられて いる．又，ジシアノ銀酸イオンの定量には試料溶液を硝 酸と硫酸で分解した後，チオシアン酸カリウムによる滴 定法で銀を定量する方法が一般に用いられている.これ らの方法により各イオンを高精度で定量することが可能 であるが，一部試料の分解を必要とするため迅速性に欠 けている.そこで, 著者は迅速性の向上を図るためシア ン化物イオンとシシシアノ銀酸イオンの逐次滴定法につい て検討した。

シアン化物イオンとシアン化合物イオンの逐次滴定に ついては，これまでに硝酸銀による電位差滴定法及び電 導度滴定法などが報告されている9) 11)。しかし，これら のほとんどがフェロシアン化物を対象としており, ジシ アノ銀酸イオンへの応用例は見当たらない.

本研究では，金電極を指示電極とする硝酸銀一電位差 滴定法を, シシシアノ銀酸カリウム及びシアン化物イオン とジシアノ銀酸イオンの混合液の分析に適用し良好な結 果が得られたので報告する.

\section{2 装置及び試薬}

\section{1 装 置}

滴定装置には平沼産業製レボーティングタイトレータ COMTITE-7 型を用い, 指示電極には同社製銀及び金電

*日本エンゲルハルド(株)市川研究所：272 千葉県 市川市中国分 3-19-3
極を，参照電極には同社製飽和硫酸水銀 (I) 電極（MS44）を使用した.

\section{$2 \cdot 2$ 試 薬}

ジシアノ銀酸カリウム：著者の事業所で製造している 特級試薬（含量 $99 \%$ 以上）を使用した。

シアン化物イオン標準溶液: 試薬特級シアン化ナトリ ウム $1.884 \mathrm{~g}$ を水に溶解し 11 とし, 硝酸銀による電位 差滴定法により標定したものを用いた。

硝酸銀標準溶液：硝酸銀 $8.5 \mathrm{~g}$ を水に溶解して 11 と し，Volhard 法により標定したものを用いた。

\section{3 実験及び結果}

\section{1 滴定操作}

試料溶液の 全量を水で $100 \mathrm{ml}$ とし, 金電極又は銀 電極と参照電極を浸して磁気かき混ぜ機でかき混ぜ, Table 1 に示す測定条件で, $0.05 \mathrm{M}$ 硝酸銀溶液を用い て電位差滴定を行う。

Table 1 Operating conditions

\begin{tabular}{ll}
\hline Delivery factor & 3 \\
Delivery sensitivity & $0 \mathrm{mV}$ \\
Interval time & $5 \mathrm{~s}$ \\
Interval sensitivity & $3 \mathrm{mV}$ \\
Buret speed & $24 \mathrm{ml} / \mathrm{min}$ \\
\hline
\end{tabular}

\section{2 電極の選定}

シアン化物イオンの電位差滴定には，指示電極とし て金属電極，イオン選択性電極などが用いられてい る2)9) 11). 本実験では，指示電極として銀電極と金電極 を用いて, 両者の此較を行った.シアン化物イオンとジ 
Table 2 Effects of contaminant ions on the determination of a mixture of cyanide ion and dicyanoargentate ion

\begin{tabular}{|c|c|c|c|c|c|c|c|}
\hline \multirow{2}{*}{$\begin{array}{l}\text { Contaminant } \\
\text { ion }\end{array}$} & \multirow{2}{*}{$\begin{array}{c}\text { Sample: } \\
\text { contaminant } \\
\text { ion } \\
(\mathrm{M}: \mathrm{M})\end{array}$} & \multicolumn{2}{|c|}{$\mathrm{CN}^{-}$} & \multirow{2}{*}{$\begin{array}{c}\text { Relative } \\
\text { error, } \\
\%\end{array}$} & \multicolumn{2}{|c|}{$\mathrm{Ag}(\mathrm{CN})_{2}-$} & \multirow{2}{*}{$\begin{array}{c}\text { Relative } \\
\text { error, } \\
\%\end{array}$} \\
\hline & & $\begin{array}{c}\text { Taken/ } \\
\text { mM }\end{array}$ & $\begin{array}{c}\text { Found/ } \\
\mathrm{mM}\end{array}$ & & $\begin{array}{c}\text { Taken/ } \\
\text { mM }\end{array}$ & $\begin{array}{c}\text { Found/ } \\
\text { mM }\end{array}$ & \\
\hline \multirow[t]{2}{*}{$\mathrm{NO}_{3}{ }^{-}$} & $1: 10$ & 5.23 & 5.25 & +0.4 & 5.37 & 5.38 & +0.2 \\
\hline & $1: 20$ & 5.23 & 5.25 & +0.4 & 5.37 & 5.36 & -0.2 \\
\hline \multirow[t]{2}{*}{$\mathrm{SO}_{4}{ }^{2-}$} & $1: 10$ & 5.23 & 5.23 & \pm 0.0 & 5.37 & 5.37 & \pm 0.0 \\
\hline & $1: 20$ & 5.23 & 5.22 & -0.2 & 5.37 & 5.38 & +0.2 \\
\hline \multirow[t]{2}{*}{$\mathrm{CO}_{3}{ }^{2-}$} & $1: 10$ & 5.23 & 5.26 & +0.6 & 5.37 & 5.34 & -0.6 \\
\hline & $1: 20$ & 5.23 & 5.24 & +0.2 & 5.37 & 5.34 & -0.6 \\
\hline \multirow[t]{2}{*}{$\mathrm{PO}_{4}{ }^{3-}$} & $1: 10$ & 5.23 & 5.23 & \pm 0.0 & 5.37 & 5.36 & -0.2 \\
\hline & $1: 20$ & 5.23 & 5.26 & +0.6 & 5.37 & 5.35 & -0.4 \\
\hline $\mathrm{Cl}^{-}$ & $1: 1$ & 5.23 & 5.21 & -0.4 & 5.37 & 5.39 & +0.4 \\
\hline $\mathrm{SCN}^{-}$ & $1: 1$ & 5.23 & 5.25 & +0.4 & 5.37 & 5.40 & +0.6 \\
\hline
\end{tabular}

シアノ銀酸イオンの混合液を両電極を用いて滴定した結 果をFig. 1 に示した. 銀電極ではジシアノ銀酸イオン に対応する変曲点のみであったが, 金電極ではシアン化 物イオンとジシアノ銀酸イオンに対応する二つの変曲点 が得られた。すなわち, 第一変曲点は式(1) に基づくシ アン化物イオンの終点 (a)を, 第二変曲点は式 (2) に基 づくシシアノ銀酸イオンの終点 $(\mathrm{b})$ を示し，(a)からシ アン化物イオンが, (b) -2 (a) からジシアノ銀酸イオン が定量できることが明らかになった。

$$
\begin{aligned}
& 2 \mathrm{CN}^{-}+\mathrm{Ag}^{+} \longrightarrow \mathrm{Ag}(\mathrm{CN})_{2}^{-} \\
& \mathrm{Ag}(\mathrm{CN})_{2}^{-}+\mathrm{Ag}^{+} \longrightarrow 2 \mathrm{AgCN}^{-}
\end{aligned}
$$

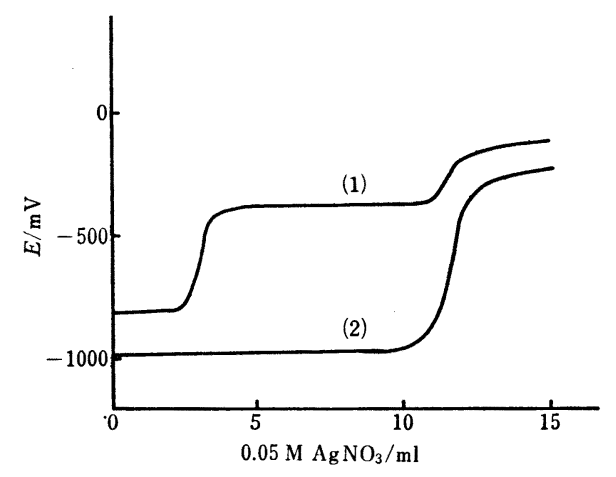

Fig. 1 Potentiometric titration curves for cyanide and dicyanoargentate ions in a mixture

(1) Gold electrode, (2) Silver electrode; Solution : $100 \mathrm{ml}$ of $3.14 \mathrm{mM}$ cyanide and $2.68 \mathrm{mM}$ dicyanoargentate ions

\section{3 pH の影響}

シアン化物イオンは, pH 7 以下では揮散するおそれ があるので, アルカリ性で滴定しなければならない，そ こで, $\mathrm{pH}$ の影響について検討した. $\mathrm{pH} 8$ から $\mathrm{pH}$
10.7 の範囲で検討したところ，この範囲では土 $1 \%$ 以 下の相対誤差で定量することができた.

\section{4 共存物の影響}

シアン化物イオン $(5.23 \mathrm{mM})$ とシシシアノ銀酸イオン $(5.37 \mathrm{mM})$ の混合液を用いて共存物質の影響について 調べた。

Table 2 に示すよらに, 1 20 倍モルの硝酸塩, 硫酸 塩, 炭酸塩及びリン酸塩が共存しても $00.5 \%$ 以内の 相対誤差で定量することができた，又，塩化物及びチオ シアン酸塩が共存しても定量値にはほとんど影響は認め られなかったが，これらのイオンの共存によりジシアノ 銀酸イオンに対応する終点の電位飛躍が小さくなった. 更に, 塩化物イオン及びチオシアン酸イオンは式(2) の 反応が終了した後, 銀イオンと反応し第三变曲点を生ず るため, シアン化物イオンとの逐次滴定が可能であると 考えられる。

\section{5 ジシアノ銀酸カリゥムの定量}

著者の事業所で製造している試薬特級ジシアノ銀酸カ リウム（含量 $99 \%$ 以上）を本法と常法（硝酸と硫酸で 分解後, チオンアン酸カリウムによる電位差滴定法）で 分析し比較したところ, Table 3 のような結果が得られ

Table 3 Determination of potassium dicyanoargentate

\begin{tabular}{cccc}
\hline Sample No. & $\begin{array}{c}\text { This method, } \\
\%\end{array}$ & $\begin{array}{c}\text { Other methodt, } \\
\%\end{array}$ & $\begin{array}{c}\text { Relative error, } \\
\%\end{array}$ \\
\hline $\mathbf{8 3 0 4 4}$ & 99.49 & 99.37 & +0.12 \\
83045 & 99.47 & 99.28 & +0.19 \\
$\mathbf{8 3 0 4 6}$ & 99.10 & 99.16 & -0.06 \\
$\mathbf{8 3 0 4 8}$ & 99.28 & 99.12 & +0.16 \\
$\mathbf{8 3 0 4 9}$ & 99.20 & 99.50 & -0.30 \\
\hline
\end{tabular}

Number of analyses : 2 ; $†$ Potentiometric titration method with potassium thiocyanate after the decomposition of sample with nitric acid and sulfuric acid 
た. ジシアノ銀酸カリウムでは, 遊離のシアン化物イオ ンが存在しないので, 銀電極, 金電極ともに一つの変曲 点のみもつ滴定曲線が得られた. 本法による定量値と常 法による定量值の間に有意差は認められなかった，又， 分析精度は相対標準偏差で本法が $0.28 \%$, 常法が 0.05 \%であった. このように, 本法は精度の面で常法に比 べ若干劣っているが, 分析の所要時間が 10 分程度であ り迅速性に優れているため, ジシアノ銀酸カリウムの簢 易分析法として十分使用できる.

\section{6 シアン化物イオンとジシアノ銀酸イオン 混合液} の定量

シアン化物イオンとジシアノ銀酸イオンの混合比の異 なる試料溶液を調製し，金電極による電位差滴定法を適 用したところ，Table 4 のような結果が得られた。これ から分かるように, 本法によりシアン化物イオンとジシ アノ銀酸イオンを 土1.0\% 以内の誤差で定量すること ができた。

Table 4 Determination of cyanide and dicyanoargentate ions

\begin{tabular}{lcccccc}
\hline No. & $\overbrace{\begin{array}{c}\text { Taken/ } \\
\mathrm{mM}\end{array}}^{\mathrm{CN}^{-}}$ & $\begin{array}{c}\text { Found/ } \\
\mathrm{mM}\end{array}$ & $\begin{array}{c}\text { Relative } \\
\text { error, } \%\end{array}$ & $\overbrace{\begin{array}{c}\text { Taken/ } \\
\mathrm{mM}\end{array}}^{\mathrm{Ag}(\mathrm{CN})_{2}-}$ & $\begin{array}{c}\text { Found/ } \\
\mathrm{mM}\end{array}$ & $\begin{array}{c}\text { Relative } \\
\text { error, \% }\end{array}$ \\
\hline 1 & 1.05 & 1.06 & +1.0 & 2.68 & 2.66 & -0.8 \\
2 & 1.05 & 1.05 & \pm 0.0 & 5.37 & 5.34 & -0.6 \\
3 & 3.14 & 3.12 & -0.6 & 1.34 & 1.34 & \pm 0.0 \\
4 & 3.14 & 3.15 & +0.3 & 2.03 & 2.02 & -0.5 \\
5 & 5.23 & 5.26 & +0.8 & 2.68 & 2.67 & -0.4 \\
6 & 5.23 & 5.26 & +0.8 & 5.37 & 5.35 & -0.4 \\
\hline
\end{tabular}

\section{交献}

1) N. H. Furman : "Standard Methods of Chemical Analysis", Vol. 1, 6th ed., (1962), (Van Nost- rand, Princeton)

2) J. F. Conrad : Talanta, 18, 952 (1971)

3) H. A. Laitinen, W. P. Jennigs, T. D. Parks : Ind. Eng. Chem., Anal. Ed., 18, 574 (1946)

4) F. Shinozuka, J. T. Stock : Anal. Chem., 34, 926 (1962)

5)池田早苗，西田義郎：分化，13，133 (1964).

6) 池田早苗, 西田義郎，吉田武：分化，13，690 (1964).

7）池田早苗，武者宗一郎：工化，72，2221（1969）。

8) 池田早苗, 武者宗一郎：工化，73，299 (1970)

9) M. Amin, M. Rumean : Ann. Chim., 2, 75 (1977).

10) J. Aspund : Talanta, 25, 137 (1978).

11) J. Aspund : Talanta, 25, 143 (1978).

拧

Successive determination of cyanide and dicyanoargentate ions by potentiometric titration with silver nitrate. Motonori Етон (Ichikawa Laboratory, Nippon Engelhard L.T.D., 3-19-3, Nakakokubun, Ichikawa-shi, Chiba 272)

A method for the successive determination of cyanide and dicyanoargentate ions in a mixed solution was studied by potentiometric titration using a gold electrode or a silver electrode as the indicator electrode. Cyanide and dicyanoargentate ions could be rapidly titrated with silver nitrate standard solution by using a gold electrode. The mixture of cyanide ion $\left(1 \times 10^{-3} \sim\right.$ $\left.5 \times 10^{-3} \mathrm{M}\right)$ and dicyanoargentate ion $\left(1.5 \times 10^{-3} \sim\right.$ $\left.5.5 \times 10^{-3} \mathrm{M}\right)$ were determined with a relative standard deviation less than $0.3 \%$. Nitrate, phosphate, carbonate and sulfate ions did not interfere with the titration. The time needed for a single titration is less than $10 \mathrm{~min}$. The recommended procedure is as follows: Place the alkaline sample solution in a 200 $\mathrm{ml}$ beaker. Dilute to about $100 \mathrm{ml}$ with water. Titrate the solution with $0.05 \mathrm{M}$ silver nitrate standard solution.

(Received June 1, 1985)

\section{Keyword phrases}

determination of cyanide and dicyanoargentate ions; potentiometric titration; gold electrode. 